\author{
FEATURES OF RECOGNITION IN FAMILIES \\ TO VIEW SOCIAL-PSYCHOLOGICAL NEEDS OF PARENTS
}

УдК 159.9.075

DOI https://doi.org/10.32843/2663-

5208.2020.12-1.24

\section{Волошенко М.О.}

к.пед.н., доцент кафредри психології та соціальної роботи

Одеський національний політехнічний університет

Герега O.P.

студент, магістрант кафредри психології та соціальної роботи

Одеський національний політехнічний університет

\begin{abstract}
У статті аналізуються чинники, що зумовлюють формування різних моделей взаємин сім'ї, які в подальшому можуть бути передумовами для проявів агресивної та ворожої поведінки дитини щодо інших людей. Як фрактор взаємин у сім'їрозглядаються базові соціально-психологічні потреби батьків. Подано результати дослідження подружніх пар і їхніх дітей-дошкільнят, які показали, що соціально-психологічні потреби матері та батька зумовлюють параметри взаємодії в сім'ї. Показано, що вираженість потреби у включенні задає високу інтенсивність позитивного ставлення до своєї сімї як у чоловіків, так і в жінок. Потреби в контролі батьків відіграють особливу роль у формуванні ставлення дитини до матері й батька Потреба матері в любові з боку інших людей задає параметри ії взаємодії зі своєю дитиною. Соціально-психологічні потреби батьків зумовлюють особливості їхньої взаємодії зі своєю дитиною меншою мірою, ніж матерів. Проведено порівняльний аналіз вираженості соціально-психологічної потреби матерів і батьків і параметрів емоційної взаємодії їх зі своєю дитиною, який показав, що в матерів дітей-дошкільнят значно більшою мірою, ніж у батьків, виражені як потреба у включенні в різні сочіальні групи, так і параметри емоиійної взаємодії з дитиною. Отримані результати свідчать про актуалізацію потреби матерів у включенні в різні соціальні групи на цьому етапі життєвого шляху, про більш емоційне включення матерів у спілкування зі своєю дитиною: вони більшою мірою прагнуть до розуміння емоційного стану дитини, виявляють емпатію та співпереживання, відчувають більшу різноманітність почуттів під час спілкування з дитиною, а також більш позитивно ставляться до себе як до батька. Ключові слова: ставлення, фрактори взаємин, взаємини в сім'ї, материнство, батьківство, сочіально-психологічні потреби.
\end{abstract}

The article analyzes the factors that lead to the formation of different models of family relationships, which in the future may be a prerequisite for the manifestation of aggressive and hostile behavior of the child towards other people. Parents' basic social and psychological needs are seen as a factor in family relationships.

The article presents the results of the study of married couples and their preschool children, who showed that the socio-psychological needs of mother and father determine the parameters of interaction in the family. The article shows that the expressed need for inclusion determines the high intensity of positive attitude towards one's family in both men and women. Parental control requires a special role in shaping the child's relationship with the mother and father. The need of the mother for love from other people sets the parameters of her interaction with the child. The socio-psychological needs of parents are less determined by the characteristics of their interaction with the child than the mother. The article presents a comparative analysis of the expressed social and psychological needs of mothers and parents and the parameters of their emotional interaction with the child, which showed that mothers of preschool children are much more likely than parents, expressed as the need for inclusion in different social groups, and the parameters of emotional interaction with the baby. The results show that mothers need to be involved in different social groups at this stage of their lives, that their mothers are more emotionally involved in communicating with their child: they are more eager to understand the emotional state of the child, are more empathetic and empathetic, experience more empathetic communication with the child, as well as a more positive attitude towards yourself as a parent. Key words: attitudes, relationship factors, family relationships, motherhood, paternity, social and psychological needs.
Постановка проблеми. Проблема взаємин особистості є головною в соціальній психології. Учені, звертаючись до аналізу факторів, що впливають на становлення й розвиток системи взаємин особистості, велику увагу приділяють взаємодії матері та дитини в ранньому онтогенезі $[1 ; 2 ; 5 ; 10]$. У сучасних дослідженнях $[1 ; 2$; $5 ; 6 ; 7 ; 10]$ виявлено, що взаємини між матір'ю та дитиною, що складаються в ранній період життя дитини, впливають на особливості ії ставлення до себе, до інших людей, на формування ставлення до світу, на особливості її соціалізації та становлення особистості. Також велика кількість досліджень присвячена вивченню феномена батьківства, впливу батька на становлення й розвиток особистості дитини $[1 ; 6]$.

\section{Аналіз останніх досліджень і публікацій.} Одним із найважливіших факторів, що впливають на особливості сімейних взаємин у ранній період життя дитини, які в подальшому відіграють значну роль у соціалізації дитини, $€$ так званий «особистісний фактор». До нього вчені зараховують різні психологічні та соціально-психологічні особливості батьків. Так, у роботах, присвячених аналізу впливу особистісних параметрів матері на формування взаємин матері та дитини, розглядалися особливості самоактуалізації особистості матері [12], ситуативна поведінка матері та різнорівневі характеристики її індивідуальності [7], психологічна готовність матері до взаємин із майбутньою дитиною [3], вік матері [5] тощо. 
У сучасних зарубіжних дослідженнях показана вплив надмірного батьківського контролю на формування локусу контролю, виникнення дезадаптивних форм поведінки і тривожності в дітей $[14 ; 15 ; 19]$. Безліч робіт зарубіжних дослідників присвячено впливу взаємин батьків між собою на формування патологічних форм поведінки в дітей. Так, в одному із сучасних досліджень [18] стверджується, що в силу дуже ранньої ідентифікації дітей із батьками наявність ворожих взаємин між ними негативно позначається на дитині, призводячи до формування агресивної поведінки. При цьому автори спробували виключити спадковий фактор, вивчаючи сім'ї з прийомними дітьми. Крім інших численних соціальних і біологічних факторів, що призводять до ворожого ставлення між батьками, цілком логічно, на наш погляд, припустити, що воно може бути також зумовлено недостатнім ступенем задоволеності їніх соціально-психологічнихпотреб. Узв'язку з цим ми вважаємо актуальним вивчення фактора формування взаємин батьків і дітей.

Постановка завдання. Метою дослідження $€$ вивчення взаємозв'язку між виразністю соціально-психологічних потреб батьків та особливістю стосунків у сім'ї. Соціально-психологічні потреби в роботі розглядаються як потреби, що формуються, виявляються та можуть бути задоволені в процесі спілкування з іншою людиною. Ми ґрунтувалися на класифікації потреб В. Шутц [16], яка чітко показує зв'язок базових соціально-психологічних потреб і сформованих на цій основі взаємин людини з іншими людьми к сферах: соціальних контактів (включення), влади й відповідальності (контролю), близьких емоційних взаємин (любові).

У дослідженні поставлено такі емпіричні завдання: 1) аналіз взаємозв'язків вираженості соціально-психологічної потреби матері/ батька та взаємин у сім'ї: взаємин матері/ батька до дитини, чоловіка/дружини, сім'ї; ставлення дитини до матері, батька, сім'ї; 2) аналіз взаємозв'язків вираженості соціально-психологічних потреб матері/батька та параметрів взаємодії в парах «мати-дитина», «батько-дитина»; 3) порівняльний аналіз вираженості соціально-психологічних потреб і параметрів взаємодії зі своєю дитиною в батьків і матерів.

Виклад основного матеріалу дослідження. Для вирішення низки поставлених завдань у дослідженні використовувалися такі методики:

1. Опитувальник міжособистісних відносин Вільяма Шутца (FIRO) в адаптації А.А. Рукавишникова [9] для діагностики вираженості трьох базових соціально-психологічних потреб особистості: потреби включення в соціальні групи, контролю та любові.
2. Колірний тест взаємин А.М. Еткінда [4] для діагностики інтенсивності неусвідомлюваних стосунків у сім'ї: ставлення дитини до матері, батька, сім'ї загалом; ставлення матері до дитини, чоловіка, сім'ї; ставлення батька до дитини, дружині, родини.

3. Опитувальник дитячо-батьківського емоційної взаємодії Е.І. Захарової [5] для діагностики вираженості таких параметрів взаємодії батьків зі своїми дітьми, як «чутливість»; «емоційне прийняття»; «поведінкові прояви емоційного взаємодії».

Вибірку дослідження становлять 47 повних сімей, що мають дітей у віці від 2 до 6 років. Усього 141 особа: 47 жінок, 47 чоловіків, 47 дітей.

Як основний метод статистичної обробки даних використано кореляційний аналіз за критерієм Спірмена. Спочатку кореляційний аналіз застосований до даних, отриманих на вибірці матерів: показників вираженості соціально-психологічних потреб; інтенсивності неусвідомлюваного ставлення матері до сім'ї, чоловіка, дитини, а також ставлення її дитини до неї, батька, сім'ї; вираженості параметрів емоційної взаємодії матері та дитини. Розглянемо результати аналізу.

По-перше, виявлено, що існує взаємозв'язок між виразністю соціально-психологічних потреб матері (потреби залежно від інших людей) та інтенсивністю її неусвідомлюваного ставлення до своєї дитини. Матері з вираженим прагненням до залежності від інших людей менш позитивно ставляться до своєї дитини. Іншими словами, «залежна» від інших мати емоційно відкидає свою дитину.

По-друге, виявлені взаємозв'язки між виразністю соціально-психологічних потреб матері та її емоційним, частково несвідомим ставленням до сім'ї та чоловіка, а також ставленням її дитини до батька. Інтенсивність неусвідомлюваного ставлення матері до сім'ї має прямі пропорційні взаємозв'язки з виразністю відразу трьох соціально-психологічних потреб - у включенні, в залежності й у любові. Також інтенсивність потреби матері в любові з боку інших безпосередньо взаємопов'язана 3 інтенсивністю ії неусвідомлюваного ставлення до свого чоловіка. Більше за всіх люблять свого чоловіка ті жінки, у яких потреба бути коханою максимальна. Крім цього, виявлена парадоксальна закономірність: потреба матері контролювати інших пропорційно взаємопов'язана з емоційним, частково несвідомим ставленням іï дитини до свого батька. Діти «контролюючих» матерів (які прагнуть до влади, авторитету, контролю над іншими людьми) емоційно «відкидають» свого батька.

По-третє, з параметрами емоційної взаємодії матері зі своєю дитиною взаємопов'язані три із шести вивчених соціально-психологіч- 
них потреб. Потреба у включенні з боку інших людей має прямий пропорційний взаємозв'язок із параметрами «орієнтація на стан дитини під час побудови взаємодії» та «надання емоційної підтримки». Потреба в залежності має зворотній пропорційний взаємозв'язок зі «ставленням до себе як до батька». Чим більше актуалізована потреба в контролі з боку інших у матері, тим менш позитивно вона ставиться до себе як до батька, до себе як до матері. Потреба бути коханою пов'язана із шістьма параметрами емоційної взаємодії матері зі своєю дитиною: 1) «розуміння причин стану»; 2) «здатність сприймати стан дитини»; 3) «уміння впливати на стан дитини»; 4) «орієнтація на стан дитини під час побудови взаємодії»; 5) «надання емоційної підтримки»; 6) «прагнення до тілесного контакту». Параметри 1-2 належать до блоку «чутливість», 3-6 до «поведінкового прояву емоційної взаємодії». Отже, соціально-психологічні особливості взаємодії матері зі своєю дитиною задає передусім її потреба в установленні близьких емоційних взаємин з боку інших людей, потреба бути коханою. Мати, яка «шукає любові», більш чутлива до своєї дитини та компетентна у взаємодії з нею: вона «зчитує» емоційні прояви дитини, прагне зрозуміти причини її емоційних переживань, орієнтується на них під час організації взаємодії з дитиною, уміє впливати на емоційний стан своєї дитини, надати їй емоційну підтримку, прагне до тілесного контакту зі своєю дитиною.

Узагальнення отриманих на вибірці матерів результатів дає змогу зробити низку висновків: 1) рівень вираженості соціально-психологічних потреб матері зумовлює її емоційне ставлення до чоловіка, своєї дитини та сім'ї, ставлення дитини до батька, а також характеристики її взаємодії з дитиною; 2) матері з високим рівнем потреби в любові з боку інших людей більш позитивно ставляться до свого чоловіка, чутливі до своєї дитини, орієнтуються й уміють впливати на її емоційний стан під час взаємодії з нею, прагнуть до тілесного контакту з дитиною, надають їй усебічну емоційну підтримку; 3) матері, що прагнуть контролю з боку інших, уникають відповідальності, не приймають свою батьківську позицію, низько оцінюють себе як батька, менш позитивно ставляться до своєї дитини.

До даних, отриманих на вибірці батьків, також застосований кореляційний аналіз за критерієм Спірмена. Загалом виявлено набагато меншу кількість взаємозв'язків між виразністю соціально-психологічних потреб чоловіків і параметрами взаємин. Їх усього чотири: 1) ставлення чоловіка до сім'ї виявилося прямо пропорційно пов'язано з виразністю в нього потреби у включенні; 2) потреба чоловіка в контролі з боку інших людей про- порційно пов'язана з інтенсивністю відносин його дитини до матері; 3) потреба у включенні в соціальні групи з боку інших людей має прямий пропорційний зв'язок із таким параметром взаємодії з дитиною, як «здатність до співпереживання»; 4) потреба в контролі з боку інших людей має зворотний пропорційний взаємозв'язок із параметром «прагнення до тілесного контакту».

Отже, високу інтенсивність позитивного ставлення до своєї сім'ї й у чоловіків, і в жінок задає вираженість базової потреби у включенні. Можна припустити, що вона не пов'язана з установленням партнерами формального союзу, а ступінь ії вираженості зумовлений зміцненням або ослабленням емоційних зв'язків між партнерами. Також на цій вибірці виявлена така закономірність: діти чоловіків із вираженою потребою в контролі з боку інших людей (схильних до залежності від інших) не приймають, емоційно відкидають свою матір, навпаки, діти «незалежних» батьків (у яких потреба в залежності від інших виражена в мінімальною мірою) з максимальним ступенем позитивності ставляться до своєї матері.

Загалом соціально-психологічні потреби батьків меншою мірою, ніж матерів, зумовлюють параметри їхньої взаємодії зі своєю дитиною. Тілесний контакт зі своїми дітьми підтримують більш «незалежні» чоловіки (з низьким ступенем вираженості потреби в контролі з боку інших людей). Велику чутливість (здатність до емпатії) у взаємодії зі своєю дитиною проявляють батьки 3 вираженою потребою у включенні.

Далі проведений порівняльний аналіз вираженості соціально-психологічних потреб матерів і батьків і параметрів їхньої взаємодії зі своєю дитиною за критерієм Манна-Уїтні (таблиця 1). Виявлені значущі відмінності дають змогу зробити висновок про таке: 1) у матерів дітей-дошкільнят значно більшою мірою, ніж у батьків, виражена потреба у включенні в різні соціальні групи; 2) у матерів значно більшою мірою, ніж у батьків, виражені параметри емоційної взаємодії зі своєю дитиною, що належать до блоків «чутливість», «емоційне прийняття» і «ставлення до себе як до батька». У поведінкових проявах емоційної взаємодії батьків і матерів зі своєю дитиною відмінностей не виявлено.

Отримані результати свідчать про актуалізацію потреби у включенні матерів на цьому етапі їхього життя - на етапі, коли дитина досягає віку від 2 до 6 років. Це період активного соціального пошуку жінок-матерів - виходу на роботу, розширення кола спілкування тощо. Також результати говорять про більш емоційне включення матерів у спілкування зі своєю дитиною. 
Таблиця 1

Результати порівняльного аналізу вираженості соціально-психологічних потреб і параметрів взаємодії зі своєю дитиною батьків і матерів за критерієм Манна-Уїтні

\begin{tabular}{|c|c|c|c|c|c|}
\hline $\begin{array}{c}\text { Пара- } \\
\text { метр }\end{array}$ & пвсг & зсСд & зС & Пввд & СБ \\
\hline $\begin{array}{c}\text { Пор. } \\
\text { ранг } \\
\text { групи } \\
\text { (батьки) }\end{array}$ & 24,38 & 24,26 & 23,12 & 23,98 & 24,33 \\
\hline $\begin{array}{c}\text { Пор. } \\
\text { ранг } \\
\text { групи } \\
\text { (матері) }\end{array}$ & 34,62 & 33,59 & 33,88 & 35,02 & 33,51 \\
\hline Z & $-2,120$ & $-1,961$ & $-2,317$ & $-2,320$ & $-2,080$ \\
\hline $\begin{array}{c}\text { Рівень } \\
\text { значу- } \\
\text { щості }\end{array}$ & 0,036 & 0,051 & 0,020 & 0,019 & 0,039 \\
\hline
\end{tabular}

Пояснення: ПВСГ - потреба у включенні в соціальні групи; ЗССД - здатність сприймати стан дитини; ЗС - здатність до співпереживання; ПВВД - почуття, що виникають під час взаємодії з дитиною; СБ - ставлення до себе як до батька.

Дослідження продемонструвало складний взаємозв'язок соціально-психологічних потреб матері, батька і ставлення їхньої дитини до них: емоційне, частково неусвідомлюване ставлення дитини до матері пов'язане з потребнісно-мотиваційною сферою батька, навпаки, емоційне прийняття/відкидання дитиною батька взаємопов'язане з низьким/ високим рівнем вираженості в матері потреби в контролі інших людей. Виявлений факт - ще одне емпіричне підтвердження базового уявлення про функціонування взаємин особистості як складної системи, уявлення, сформульованого як на рівні фундаментальної соціальної психології [8], так і в рамках різних підходів до корекції взаємин людини [17].

Отримані результати також показують, що особливості міжособистісної взаємодії в парі «мати-дитина» більшою мірою «задані» особистісним фактором (яким у дослідженні стали 6 базових соціально-психологічних потреб), ніж параметри міжособистісної взаємодії в парі «батько-дитина», що підтверджує виявлені в численних дослідженнях відмінності у феномені материнства та батьківства [1;2; 3; 5; 11].

Висновки 3 проведеного дослідження. У дослідженні показано, що соціально-психологічні потреби матері та батька зумовлюють параметри взаємодії в парах «мати-дитина» та «батько-дитина», а також ставлення матері/ батька до сім'ї, чоловіка/дружини і ставлення дитини до матері/батька.

Виразність потреби матері в любові з боку інших людей задає параметри її взаємодії зі своєю дитиною. Матері, які мають високий рівень вираженості цієї потреби, позитивно ставляться до свого чоловіка, демонструють високий рівень чутливості до своєї дитини, прагнення до тілесного контакту, орієнтуються й уміють впливати на емоційний стан дитини під час побудови взаємодії. Соціально-психологічні потреби батьків меншою мірою, ніж матерів, зумовлюють параметри їхньої взаємодії зі своєю дитиною: тілесний контакт зі своїми дітьми підтримують більш «незалежні» чоловіки, здатність до емпатії у взаємодії зі своєю дитиною проявляють батьки з вираженою потребою у включенні.

Виразність базової соціально-психологічної потреби у включенні задає високу інтенсивність позитивного ставлення до своєї сім'ї як у чоловіків, так і в жінок, при цьому ставлення жінок до своєї сім'ї зумовлено цілим комплексом соціально-психологічних потреб: поряд із виразністю потреби у включенні в нього входять потреба в любові та потреба в контролі з боку інших людей.

Потреби в контролі/залежності батьків відіграють особливу роль у формуванні ставлення дитини до матері та батька. Діти «контролюючих» матерів менш позитивно ставляться до свого батька, емоційно «відкидають» його; діти «незалежних» батьків із максимальним ступенем інтенсивності позитивно ставляться до своєї матері.

Також виявлені значущі відмінності у вираженості соціально-психологічних потреб і параметрів емоційної взаємодії зі своєю дитиною в батьків і матерів.

\section{ЛІТЕРАТУРА:}

1. Авдеева Н.Н. Роль матери и отца в развитии ребенка в раннем возрасте. Дошкольное воспитанue. 2005. № 3. С. 101-106; 2005. № 5. С. 110-117; 2005. № 7. C. 117-123.

2. Авдеева Н.Н., Мещерякова С.Ю. Вы и младенец: У истоков общения. Москва : Педагогика, 1991. $160 \mathrm{c}$.

3. Антонович О.С. Формирование психологической готовности родителей к взаимоотношению с будущим ребенком : автореср. дисс. ... канд. психол. наук. Самара, 2009.

4. Бодалев А.А., Столин В.В., Аванесов В.С. Общая психодиагностика. Санкт-Петербург : Речь, 2000. $440 \mathrm{c}$.

5. Захарова Е.И. Особенности детско-родительских отношений матерей с детьми подросткового возраста в условиях позднего материнства. Психологическая наука и образование. 2014. Т. 6. № 4. URL: http://psyedu.ru/journal/2014/4/Zakharova.phtml (дата обращения: 20.04.2020).

6. Латишева Ю.А. Феномен отцовства: современные исследования психологии. Вестник КГУ им. Н.А. Некрасова. 2013. Том 19. С. 47-51.

7. Мухамедрахимов Р.Ж. Психологическое взаимодействие матери и ребенка : автореф. дисс. ... докт. психол. наук. Санкт-Петербург, 1999. 


\section{ГАБІТУС}

8. Мясищев В.Н. Психология отношений : избранные психологические труды. Москва : Институт практической психологии ; Воронеж : НПО «МОДЭК», 1998. 368 с.

9. Рукавишников А.А. Опросник межличностных отношений. Москва : Когито-Центр, 2006.

10. Тащёва А.И., Бедрединова С.В., Малышко Л.Н. Эмпирическое исследование личностных особенностей младших школьников из неполных семей в связи с их полом. Теоретические и прикладные аспекты современной науки. 2015. № 7/10. С. 153-155.

11. Филиппова Г.Г. Психология материнства : учебное пособие. Москва : Изд-во Института психотерапии, 2002. 240 с.

12. Хозяинова Т.К. Особенности самоактуализации личности матери как фрактор ее отношения к детям : дисс. ... канд. психол. наук. Краснодар, 2004. 154 c.

13. Bernet W., Wamboldt M.Z., Narrow W.E. Child Affected by Parental Relationship Distress. Journal of the American Academy of Child \& Adolescent Psychiatry. 2016. № 55 (7). P. 571.
14. Bruggen van der C.O., Bögels S.M., Zeilst van $\mathrm{N}$. What influences parental controlling behaviour? The role of parent and child trait anxiety. Cognition and Emotion. 2010. V. 24 (1). P. 141-149.

15. Morton T.L., Mann B.J. The Relationship between Parental Controlling Behavior and Perceptions of Control of Preadolescent Children and Adolescents. Journal of Genetic Psychology. 1998. V. 159 (4). P. 477-491.

16. Schutz W. FIRO: A Three-Dimensional Theory of Interpersonal Behavior. New York, NY : Rinehart, 1958.

17. Shkurko T.А., Зинченко Е., Serikov G. Актуальные вопросы теории и практики психологической помощи личности в трудной жизненной ситуации. Российский психологический журнал. 2018. № 6. С. 25.

18. Stover C.S., Zhou Y., Kiselica A et al. Marital Hostility, Hostile Parenting, and Child Aggression: Associations From Toddlerhood to School Age. Journal of the American Academy of Child \& Adolescent Psychiatry. 2016. № 55 (3). P. 235-242.

19. Thirlwall Kerstin \& Creswell Cathy. The impact of maternal control on children's anxious cognitions, behaviours and affect: An experimental study. Behaviour research and therapy. 2010. № 48 (10). P. 1041. 